\title{
Students' Attitudes on the Use of Machine Translation in Japanese Language Class
}

\author{
Irawati Agustine', Kun Makhsusy Permatasari²
}

DOI: 10.35445/alishlah.v13i3.1461

\begin{abstract}
Article Info
Keywords:

Attitude,

Language,

Japanese,

Machine,

Translation,

Kata kunci:

Sikap,

Bahasa,

Jepang,

Mesin,

Terjemah

\section{Abstract}

The purpose of the study was to determine student attitudes towards the use of machine translation in Japanese classes, especially in Writing 1 and IV classes. Machine Translation is considered an online resource in facilitating the translation process. The method used is descriptive qualitative. Data were taken from questionnaires distributed to students. Participants are semester II and semester IV students who receive Japanese Writing courses. This research activity was conducted at a private University, Jakarta. The data analysis technique used three stages: data reduction, data presentation, and concluding. The results showed that students were dissatisfied with the use of machine translation. This means that the student's attitude is negative. However, machine translation is considered to help complete the translation task more quickly, but the translation results are not in the context of the target language.

Abstrak

Penelitian ini bertujuan untuk mengetahui sikap mahasiswa terhadap penggunaan mesin terjemah di kelas Bahasa Jepang khususnya pada kelas mata kuliah Menulis 1 dan IV. Mesin Terjemah dianggap sebagai sumber daya daring dalam memudahkan proses penerjemahan. Metode yang digunakan adalah kualitatif deskriptif. Data diambil dari kuesioner yang disebarkan kepada mahasiswa. Partisipan adalah mahasiswa semester II dan semester IV yang mendapatkan mata kuliah Menulis Bahasa Jepang. Kegiatan penelitian ini dilakukan di Universitas Swasta Jakarta. Teknik analisis data menggunakan tiga tahap yaotu reduksi data, penyajian data dan penarikan simpulan. Hasil penelitian menunjukkan bahwa mahasiswa merasa tidak puas terhadap penggunaan mesin terjemah. Artinya bahwa sikap mahasiswa negatif. Namun, mesin terjemah dianggap bisa membantu menyelesaikan tugas terjemahan lebih cepat, namun hasil terjemahan tidak sesuai konteks bahasa sasaran.
\end{abstract}

\section{INTRODUCTION}

Translation as a form of human activity in language has become a professional part of the profession for people who have foreign language proficiency. From the translation process, everyone can know the history of human civilization to the development of the world today. Through translation, one can understand the content of the information they want to know. Recent developments in machine translation, such as in Google Translate, can help second language (L2) writers produce text in the target language according to its intended meaning (Chon et al., 2021).

\footnotetext{
${ }^{1}$ Universitas Darma Persada Jakarta, Indonesia

Email: irawati_agustine@fs.unsada.ac.id

2 Universitas Darma Persada Jakarta, Indonesia

Email: kun_makhsusy_permatasari@fs.unsada.ac.id
}

Vol.13 (3) December, 2021

Received: November 30, 2021; Received in revised form: December 12, 2021; Accepted: December 25, 2021; Available online: December 31, 2021. This is an open access article under a Creative Commons Attribution-NonCommercial-ShareAlike 4.o International License. 
Machine Translation (MT) also refers to automated attempts to translate words, phrases, text, or speech from one language to another. Machine Translation (MT) is another option for recognizing the meaning of a foreign language. Machine Translation can also be used like a dictionary. MT is very useful and helpful. It can provide an overview to the user and provide inspiration or consideration to understand its meaning (Sujarwo, 2020). So, google translate is often used as one of the translation machines used in foreign language classes such as Japanese.

Moreover, current technological advances have made it easier for the learning process of foreign language translation because students can easily use machine translators to translate text. Technology provides many benefits for second language teachers or translation trainers in the translation process (Carrió-Pastor, 2016). Various online resources are available and make it easy for students to access learning resources anytime and anywhere, even the latest variety of learning content. In addition, the online learning process during the COVID-19 pandemic has been supported by various technological resources in achieving learning objectives. As in the Japanese class at Private University, Jakarta. The result of the preliminary study showed that students often use machine translation to complete translation tasks given by the lecturer. However, the translation results often do not meet the expected context. However, some students often say that machine translation provides convenience in completing translation tasks.

The results of interviews with semester 1 students for the 2020-2021 academic year show that students like various online resources such as Google Translate, but according to them, translation machines also often produce translations that are not by the target language. However, Tsai (2019) showed that students were satisfied with the translation results from Google Translate. It can be seen that students often use Google Translate as a medium to translate Indonesian text into Japanese or vice versa. These tools help students translate Japanese text into Indonesian easily.

The last studies are related to machine translation in foreign language teaching and learning. Machine Translation has a positive impact on students' translation results (Sabtan, 2020), and they can complete translation tasks effectively and efficiently in a short time (Mahardika, 2017). Most educators are aware that some students use web-based machine translators for foreign language assignments. Students have varying beliefs about the usefulness of machine translators for writing assignments, and many of them can articulate and reflect on the strategies they use (White \& Heidrich, 2013). Especially at this time, many students and teachers have been involved in technology in the teaching and learning process (Barr, 2013). The era of digital technology has become a must for use in language classes. So, nowadays, machine translation has become a complex dynamic in classroom teaching (Niño, 2009). The use of MT highlights the strengths and limitations of this technology, explores 21st-century pedagogical solutions designed to leverage the capabilities of MT and alternative technologies, and suggests places for future research to ensure student academic growth in the field of translation (Ducar \& Schocket, 2018). It can be concluded that the diverse dynamics of various perspectives on the existence of machine translation illustrates that technology has been able to provide great benefits in achieving teaching and learning objectives.

However, this research explores students' attitudes towards the implementation of machine translation related to Japanese language classes. This attitude is directed at exploring their understanding related to the accuracy of the translation of Japanese texts in the classroom according to the context of the target language. So far, previous research has viewed machine translation as a tool that can help students translate foreign languages briefly and correctly or precisely. But this study offers a different concept. Awareness of students in using various technology applications for machine translation is essential for adjusting the context of the target language. This means that whether students will use the translation as a whole or make adjustments to the context of the target language.

Thus, the purpose of this study was to determine student attitudes towards the use of machine translation in Japanese classes. To see if the result of this machine translation by the context of the target language. Thus, this research is expected to provide an in-depth understanding related to the 
use of machine translation in the classroom as a multimedia technology or online resource that makes it easier for them to translate Japanese texts.

\section{METHODS}

The participants in this study were students in the second and fourth semester of the 20202021 academic year in the Japanese undergraduate study program at Darma Persada University, Jakarta. The participants were 60 students $(\mathrm{F}=28, \mathrm{M}=32)$ who received the Writing (semester IV) course. Participants were randomly selected according to their willingness to participate. The research activity was carried out for three months, from March-May 2021. So, the method in this study was to explore student attitudes towards the use of machine translators to translate Japanese essay text into Indonesian or vice versa. This research method is called qualitative (Creswell, 2012; Yin, 2011). This research uses the descriptive qualitative method because it describes the phenomenon of facts related to students' attitudes towards using machine translators in writing class.

Primary data were interviews and questionnaires distributed to students in Japanese writing classes. While the primary data is taken from journals and literature reviews. The questionnaire was designed to refer to the research results from Kumar (2012) so that it is considered valid and reliable. The data analysis process uses the Miles and Huberman model through data reduction, data presentation, drawing conclusions and triangulation (Miles \& Huberman, 1994).

\section{FINDINGS AND DISCUSSION}

Data on distributing questionnaires to students that have been analyzed are presented in the form of graphs with percentages for each question item, which are presented in the following table and graph:

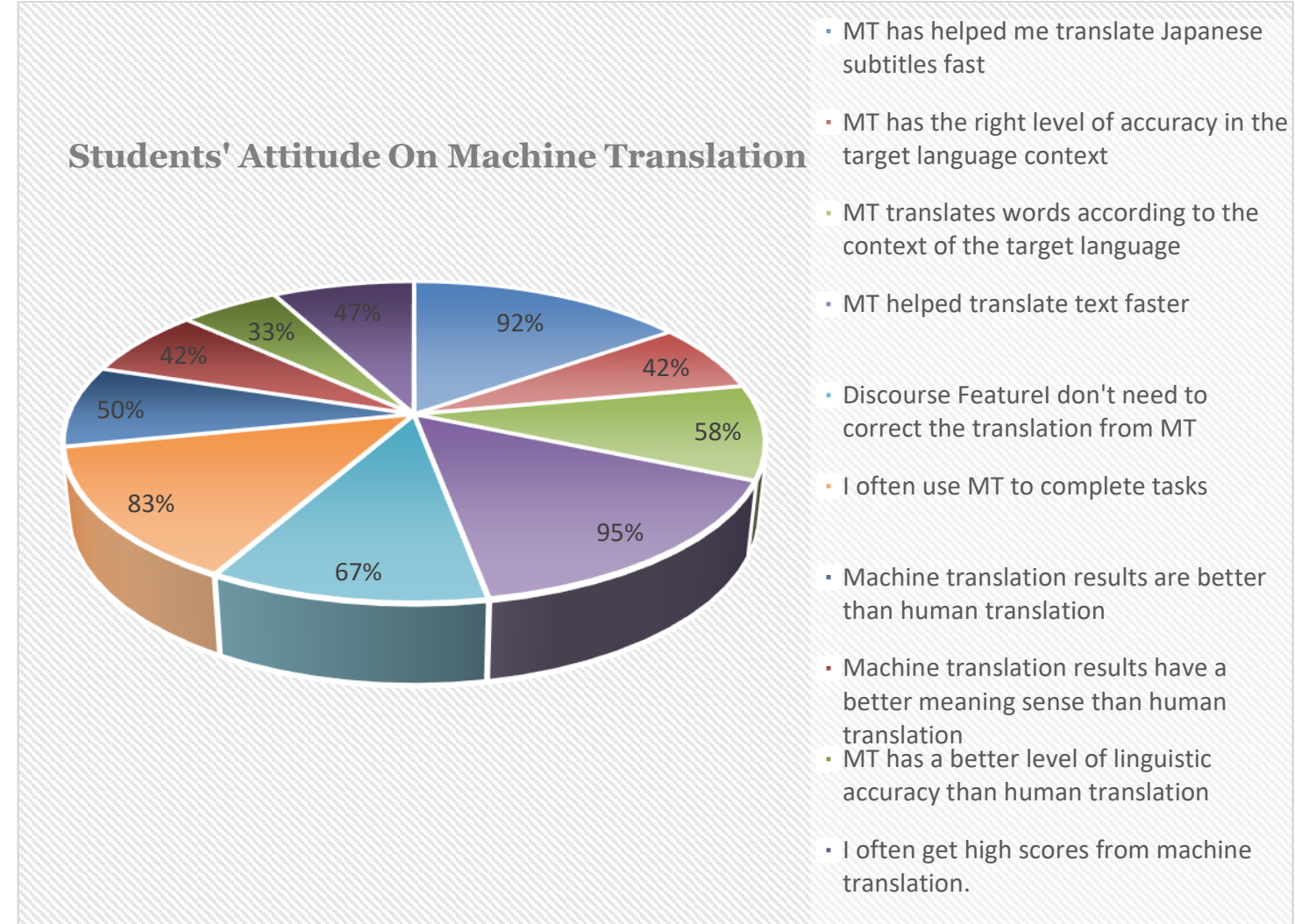

Graph 1. Percentage of Questionnaire about Students' Attitude on Machine Translation 
The students' answers that indicated the agreeable answers were made an average value according to the gender of the participants so that this study could determine the attitudes between male and female students. The following the average of questionnaire score as gender aspect;

Table 1. The Average of questionnaire data

\begin{tabular}{lrr}
\hline \multicolumn{1}{c}{ Statement } & \multicolumn{2}{c}{ Average } \\
\cline { 2 - 3 } & \multicolumn{1}{c}{$\mathrm{F}$} & $\mathrm{M}$ \\
\hline MT has helped me translate Japanese subtitles fast & 0,5 & 0,42 \\
MT has the right level of accuracy in the target language context & 0,25 & 0,17 \\
MT translates words according to the context of the target language & 0,3 & 0,28 \\
MT helped translate text faster & 0,53 & 0,42 \\
Discourse FeatureI don't need to correct the translation from MT & 0,333 & 0,33 \\
I often use MT to complete tasks & 0,38 & 0,45 \\
Machine translation results are better than human translation & 0,212 & 0,28 \\
Machine translation results have a better meaning sense than human translation & 0,25 & 0,17 \\
MT has a better level of linguistic accuracy than human translation & 0,17 & 0,167 \\
I often get high scores from machine translation. & 0,25 & 0,22 \\
\hline
\end{tabular}

Data from the table and graph shows that Machine Translation makes it easy for Japanese class students in translating Japanese text into Indonesian and provides faster time. This can be seen from the percentage above $80 \%$. However, students believe that machine translation does not provide better translation results than human translation because the translated text is often not by the context of the target language. This means that the level of accuracy is less satisfying for students. They must make corrections to the Japanese text translated into Indonesian again according to Japanese grammar and the context of the target language. In addition, the meaning obtained is also not by the sense expected in the target language. So, students who complete the translation task using machine translation without corrections get lower scores than students who correct the results of machine translation. The results of interviews with participants reinforce this. The results of the interview transcripts related to their attitudes are:

Student A: "I get a low score if I submit a translation assignment without being corrected first."

Student B: "I got a satisfactory score (9o) from using machine translation and made corrections before submitting it."

Students (2O people) said that they were not satisfied with using machine translation for translation results and the translation results were not by the context of the target language.

While the results of the questionnaire analysis related to machine translation satisfaction are depicted in the second graph;

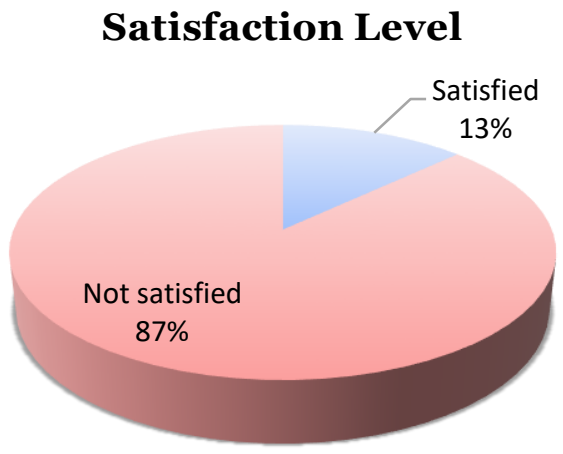

Graph 2. Students' Satisfaction Level 
Graph 2 shows students' attitudes towards the use of machine translation because the translation results are not by the context of the target language. Machines are not the same as humans. These evolving technologies are not designed for language learning and, as a result, have limited capabilities at present depending on language pairs, language directions, genres, etc (Niño, 2020). This machine translation is a tool that can only be used to help the translation process go faster, but the content of the translated text must still be adjusted to the target language you want to use. Uliyanti et al. (2021) conclude that although translation tools have a good impact on students, there are some problematic points using translation tools. Students are advised to check and recheck their translation results in the target language. Translation tools also help students in doing writing assignments, although there are some positive and negative impacts on students' use of translation tools.

Nowadays it cannot be denied that online translators have become a component of language learning. Students should still be able to use the dictionary as a companion to correct the translation results (O’Neill, 2019). However, these findings differ from the results of Lee's study (2020) which concluded that MT helps students reduce lexico-grammatical errors. Students also view the use of MT while writing positively. This study found that MT can be a useful aid for language learning, but for it to be beneficial for student learning, teachers must be aware of its limitations and provide adequate guidance to students.

So, teachers must provide clear guidance to students in using machine translation so that they can know the context of the purpose of the translation. The main goal of translation is to produce a translation that is as close as possible to the original text. Although in reality, it is not possible to produce a perfect translation that is the same as the original manuscript. There are always things that can't be translated properly. This understanding leads students that machine translation also does not produce the same translated text as the source-language text. However, as digital technology develops, machine translation (MT), improves its ability to translate with grammatical and lexical accuracy and is also becoming increasingly available to language students for academic purposes. Given the acceptance of other digital technologies for teaching and learning, it is likely that machine translation will become a tool that students will rely on to complete their assignments in a second language. MT will continue to evolve, that this technology will have a major impact on the teaching of Languages for Academic Purposes, and with imaginative use, will enable this influence to be positive for both students and teachers (Groves \& Mundt, 2015)

\section{CONCLUSION}

The study results concluded that students showed a dissatisfied attitude towards machine translation for the translation results. This means that the translation results from the machine translation are not by the context of the target language. However, the translation process helps students more easily and faster complete the translation task. The results of the translation must be corrected again according to Japanese grammar and the context of the target language. Thus, students' attitudes towards the involvement of technology such as machine translation do benefit the translation learning process. However, the results of this study have implications for understanding the concept of using multimedia technology such as machine translation for Japanese translation classes. Machine translation cannot be considered $100 \%$ to produce translations by the context of the target language in the translation process. This is because the machine is man-made and has limitations. So, every student still has to make corrections to every sentence generated from the machine translation to match the context of the target language. Thus, educators can understand learning media that students can use as learning aids because digital media has become an inseparable part of the teaching and learning process.

The results of this translation are still limited to students' views on machine translation in the Japanese Translation class. The results found are related specifically to the translation results, whether they match the context of the target language or not. So, the results of this study can still be 
developed. Further researchers can develop the results of this study more broadly, such as comparing the results of machine translation with human translation. Grammatical rules cannot be ignored in the translation process because they will affect the meaning contained in the source language sentences. The grammatical level of language certainly differs from one language to another. Likewise, the grammatical level in Japanese is certainly different from the grammatical level in Indonesian.

\section{REFERENCES}

Barr, D. (2013). Embedding technology in translation teaching: Evaluative considerations for courseware integration. Computer Assisted Language Learning, 26(4), 295-310. https://doi.org/10.1080/09588221.2012.658406

Carrió-Pastor, M. L. (2016). Technology Implementation in Second Language Teaching and Translation Studies. New Frontiers in Translation Studies. https://doi.org/10.1007/978-98110-0572-5

Chon, Y. V., Shin, D., \& Kim, G. E. (2021). Comparing L2 learners' writing against parallel machinetranslated texts: Raters' assessment, linguistic complexity and errors. System, 96, 102408. https://doi.org/10.1016/J.SYSTEM.2020.102408

Creswell, J. W. (2012). Research, educational planning, conducting, and evaluating quantitative and qualitative research. Pearson Education.

Ducar, C., \& Schocket, D. H. (2018). Machine translation and the L2 classroom: Pedagogical solutions for making peace with Google translate. Foreign Language Annals, 51(4), 779-795. https://doi.org/10.1111/FLAN.12366

Groves, M., \& Mundt, K. (2015). Friend or foe? Google Translate in language for academic purposes. English for Specific Purposes, 37, 112-121. https://doi.org/10.1016/J.ESP.2014.09.001

Kumar, A. (2012). Machine Translation in Arabic-Speaking ELT Classrooms: Applications and Implications. International Journal of Social Science and Humanity, 2(6), 442-445. https://doi.org/DOI: 10.7763/IJSSH.2012.V2.142

Lee, S. M. (2020). The impact of using machine translation on EFL students' writing. Computer $\begin{array}{llll}\text { Assisted Language } \quad \text { Learning, } & \text { 33(3), }\end{array}$ https://doi.org/10.1080/09588221.2018.1553186

Mahardika, R. (2017). The Use Of Translation Tool In Efl Learning: Do Machine Translation Give Positive Impact In Language Learning? Pedagogy : Journal of English Language Teaching, 5(1), 49-56. https://doi.org/10.32332/PEDAGOGY.V5I1.755

Miles, M. B., \& Huberman, A. M. (1994). Qualitative Data Analysis; An Expanded Sourcebook. Sage Publication.

Niño, A. (2009). Machine translation in foreign language learning: language learners' and tutors' perceptions of its advantages and disadvantages. ReCALL, 21(2), 241-258. https://doi.org/10.1017/S0958344009000172

Niño, A. (2020). Exploring the use of online machine translation for independent language learning. Research in Learning Technology, 28, 1-32. https://doi.org/10.25304/RLT.V28.2402

O'Neill, E. M. (2019). Training students to use online translators and dictionaries: The impact on second language writing scores. International Journal of Research Studies in Language Learning, 8(2). https://doi.org/10.5861/IJRSLL.2019.4002

Sabtan, Y. M. N. (2020). Teaching Arabic Machine Translation to EFL Student Translators: A Case Study of Omani Translation Undergraduates. International Journal of English Linguistics, 1O(2), 184. https://doi.org/10.5539/IJEL.V10N2P184

Sujarwo, S. (2020). Students' Perceptions of Using Machine Translation Tools In the EFL Classroom. Al-Lisan: Jurnal Bahasa (e-Journal), 5(2), 230-241. https://doi.org/10.30603/AL.V6I2.1333

Tsai, S. C. (2019). Using google translate in EFL drafts: a preliminary investigation. Computer $\begin{array}{llll}\text { Assisted Language } \quad \text { Learning, } & \text { 32(5-6), }\end{array}$ https://doi.org/10.1080/09588221.2018.1527361

Uliyanti, E., Br Bangun, P., \& Mustafa, S. M. (2021). TRANSLATION TOOL TECHNOLOGY TREND: WHAT ARE THE IMPACTS FOR THE STUDENTS? International Journal of Educational Management and Innovation, 2(1), 77-87. https://doi.org/10.12928/IJEMI.V2I1.3174 
White, K. D., \& Heidrich, E. (2013). Our Policies, Their Text: German Language Students' Strategies with and Beliefs about Web-Based Machine Translation. Die Unterrichtspraxis/Teaching German, 46(2), 230-250. https://doi.org/10.1111/TGER.10143

Yin, R. K. (2011). Aplikasi penelitian studi kasus. Thousand Oak. 
Al- Ishlah: Jurnal Pendidikan, December 2021, 13 (3), Pages 2557-2564

Irawati Agustine, Kun Makhsusy Permatasari

This page is intentionally left blank 